\title{
Stake of a Cold Chain in Sub-Saharan Countries and
}

\section{Attempt of News Strategies}

\author{
Kemajou Alexis \\ Laboratory of Refrigeration and Air conditioning, Advanced Teachers Training College for Technical Education, University of \\ Douala, P.O. Box 1872, Douala, Cameroon
}

Received: Feburary 13, 2012 / Published: April 20, 2012.

\begin{abstract}
This article shows out the situation of cold chain in sub-Saharan countries through an investigation carry out in 34 cold stores in Cameroon. The cold chain in sub-Saharan countries still remains uncertain. The stacking conditions are hardly respected and are especially limited on temperature control. The equipments of transportation of refrigerated foodstuff and the display cases made for the selling of perishable foodstuff are poorly used. And, many consumers do not have domestic refrigerators to store products. The main reasons for this situation are: poverty, unawareness, unqualified refrigeration technicians and finally an insufficient political policy. Nevertheless, some solutions could be outlined: sensitisation and training at different levels, an international support based on the training and the respect of cold chain norms, the promotion of traditional food conservation techniques (drying, smoking, salting) which are more accessible and appropriate to local feeding styles.
\end{abstract}

Key words: Africa, cold chain, foodstuff, chilling, drying, smoking.

\section{Introduction}

In most of the countries, the cold chain is applied on more than half of the consumed food [1]. The increasing demand for fresh product having a long period of conservation generates a number of risks exacerbated by the phenomenon of massive consumption. The application of the cold chain is therefore important for the good preservation of perishables foodstuff in order to provide to consumers healthy and safe products. The main rule for the use of cold is summarized in the "trépied frigorifique", which means: healthy product, rapid submission to cold, preservation to cold continuously till the consumption [2, 3]. There are requirements for production, handling and distribution of foodstuff defined by international and national standards. In the agreement on the International Carriage of Perishable Foodstuffs and on the Special Equipment used for

Corresponding author: Kemajou Alexis, senior lecturer, research fields: energy auditing and food preservation. E-mail: kemajoualexis@yahoo.fr. such Carriage (ATP) [4], frozen foods and deep-frozen are two different types of products. According to European's Directive 89/108 [5], the temperature of deep-frozen foods should be stable and maintained in different parts of the product at $-18{ }^{\circ} \mathrm{C}$ or lower. This requirement $[6,7]$ is useful because it means one can stop the freezing process before the temperature at the center of the product reaches at $-18{ }^{\circ} \mathrm{C}$. The temperature of frozen foods should be kept at a temperature less than or equal to $-12{ }^{\circ} \mathrm{C}$. For the chilling of foodstuff, each category of foodstuff has a specific range of stacking temperature, while maintaining the stacking area at a relative humidity allowing foodstuff not to undergo an excessive loss of water content and without favouring the development of germs and mold. The International Institute of Refrigeration (IIR) recommends for most perishable products $[8,9]$ a relative humidity in storage areas that range from $85 \%$ to $90 \%$. The movement of air in the cold store above $0{ }^{\circ} \mathrm{C}$ should be sufficient to maintain at any point of the storage area a uniform and 
permanent temperature and relative humidity. Some foods that emit $\mathrm{CO}_{2}$ and esters, require strong ventilation, while for frozen products, the ventilation should be quite moderate [10]. In Cameroon, there are many laws and ordinances or decrees related to the preservation of perishable foodstuff [11-14]. These laws and ordinances are in accordance with the recommendations of the IIR on optimal storage conditions for perishables.

In sub-Saharan countries, more than half the foodstuff consumed locally comes from the importation of European countries and especially South East Asia [9]. These imported products from production follow the standards as far as their origins, the conditions of manufacturing, packs and packing are concerned. Also, the packaging and transport till destination obey the standards and the practices in the study of Devaux [15]: fast cooling, controlled atmosphere, temperature monitoring using a recorder, appropriate storage. Local production of foodstuff is mainly from farming, livestock and fisheries. The later activities are still limited to the traditional state. In Cameroon in 1998 [16] for example, the local fishing using motorized canoes or paddle, produced almost 45,000 tons of fish over 120,000 tons consumed locally. The remaining production comes from industrial fishing practiced with fishing boats and trawlers on the high seas. The local production in farming and cattle farming undergone very little processing and is consumed almost immediately after collection, because of insufficient foodstuff industries. The protective action of cold lasts only during the time of application. This requires keeping food to cold, from the production to the consumer. At this level, the risks of contamination of travelling perishable foodstuff are many, due to the malfunctioning of the local distribution systems. Foodstuff processing industries do enough effort to get healthy products, but their old equipments do not allow them to achieve their goals: poor conditioning of the processing surrounding, improper treatment of water, etc.. If the cold chain is not met, the consequences can be in different forms, from the rapid wilting of plant food including vegetables, until the development of spoilage flora that devalues food, or, more seriously, flora pathogens or toxins that can lead to food poisoning. In this article, a study is done in sub-Saharan Africa: The case of Cameroon located between latitudes $2^{\circ}$ and $13^{\circ}$ North, in other to show out the cold chain's situation.

\section{Materials and Methods}

\subsection{Materials}

Authors have measured in the cold stores: the ambient temperature of air with the help of an electronic thermometer having as sensibility $+/-0.1{ }^{\circ} \mathrm{C}$; the relative humidity of air with the help of an electronic hygrometer having as sensibility $+/-5 \%$; the air speed with the help of an anemometer having as sensibility $0.05 \mathrm{~m} / \mathrm{s}$.

\subsection{Method}

\subsubsection{The Study Area}

Investigations in positive and negative temperature cold stores took place in the town of Yaounde (latitude $3^{\circ} 52^{\prime}$, longitude $11^{\circ} 32^{\prime}$ ) and the town of Douala (latitude $04^{\circ} 01^{\prime}$, longitude $09^{\circ} 44^{\prime}$ ). These two cities are characterized by abundant rainfall which undergoes the influence of mountains (Yaoundé: $1,597 \mathrm{~mm}$ of water per year, Douala: $4,125 \mathrm{~mm}$ of water per year). Douala is a coastal town dominated by a hot and humid temperature inducing an unhealthy climate (the ambient temperature is $26.4{ }^{\circ} \mathrm{C}$ and the relative humidity of air is $83 \%$ ) while, Yaounde located at 753 meters has a moderate temperature (the ambient temperature is $23.5{ }^{\circ} \mathrm{C}$ and the relative humidity is $79 \%$ ). The investigation in negative and positive temperature cold stores is done during the months of February, March and April on a sample of 34 cold stores that is 21 negative temperature and 13 positive temperature cold stores. Cameroon currently has nearly 50 cold stores, but investigations are 
conducted in the 34 largest. This distribution is fairly representative of the Cameroonian territory in that both cities represent about $80 \%$ of cold stores and focal points of all economic activities in Cameroon.

\subsubsection{Data Collection}

During investigations, the following parameters are collected: the ambient temperature; the relative humidity of air; the nature and quality of stored products; the arrangement of stored products; storage account; the conservation length; the stacking density; the cold stores' volumes; the means used for the transportation to the distribution of stored products; hygiene and sanitation conditions; the training standard of technicians on the techniques of preservation and microbiology applied to foodstuff.

\subsubsection{Data Treatment}

Cold stores were anonymous and codified. We came out with histograms of temperature, relative humidity, stacking density for positive and negative temperature cold stores.

This allowed us to evaluate the results according to the standard on the conservation of chilled and frozen foodstuff.

\section{Results}

The consumers represent the last link of the cold chain. In sub-Saharan areas, more than half of urban households and about $80 \%$ of rural households do not posses refrigerators [17]. In Cameroon, an investigation relative to the conservation of animal products (meat, fish and poultry) in cold stores has been carried out. The results from this study are presented in the graphs of Figs. 1 and 2.

\subsection{Evolution of the Temperature Curve in the Cold Stores}

\subsubsection{Frozen Products}

The histogram in Fig. 1 shows four types of negative cold stores: those whose temperatures are comprised between $0{ }^{\circ} \mathrm{C}$ and $4{ }^{\circ} \mathrm{C}$, which represent 9.54\%; those whose temperatures are comprised between $-12{ }^{\circ} \mathrm{C}$ and $0{ }^{\circ} \mathrm{C}$ that is $61.90 \%$; those whose temperature are comprised between $-18{ }^{\circ} \mathrm{C}$ and $-12{ }^{\circ} \mathrm{C}$ that is $4.76 \%$; those whose temperatures are above $-18{ }^{\circ} \mathrm{C}$, that is $23.8 \%$.

The recommended temperature for proper preservation of frozen products is at least $-18{ }^{\circ} \mathrm{C}[1]$, but we find that $76.20 \%$ of negative cold stores do not comply.

\subsubsection{Refrigerated Products}

Results of investigations show out three categories of positive cold stores: those with temperatures above

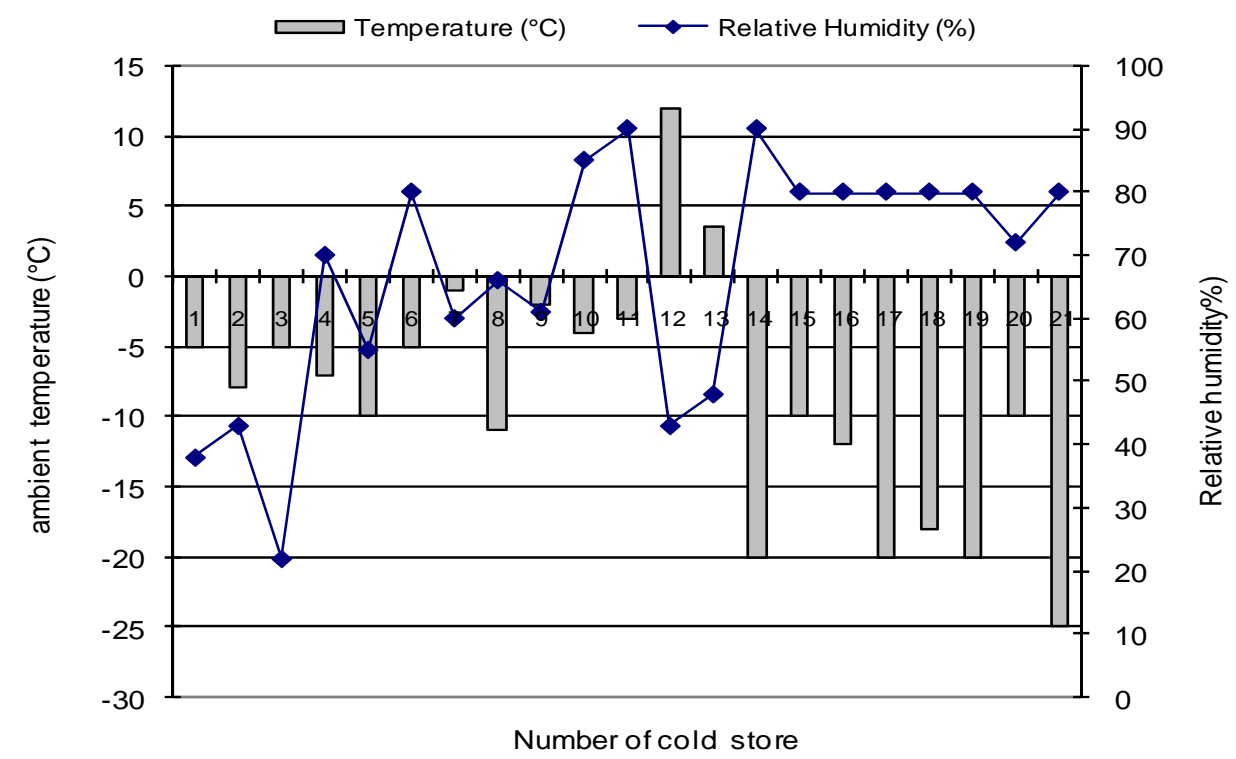

Fig. 1 Ambient temperature and relative humidity of investigated cold stores. 


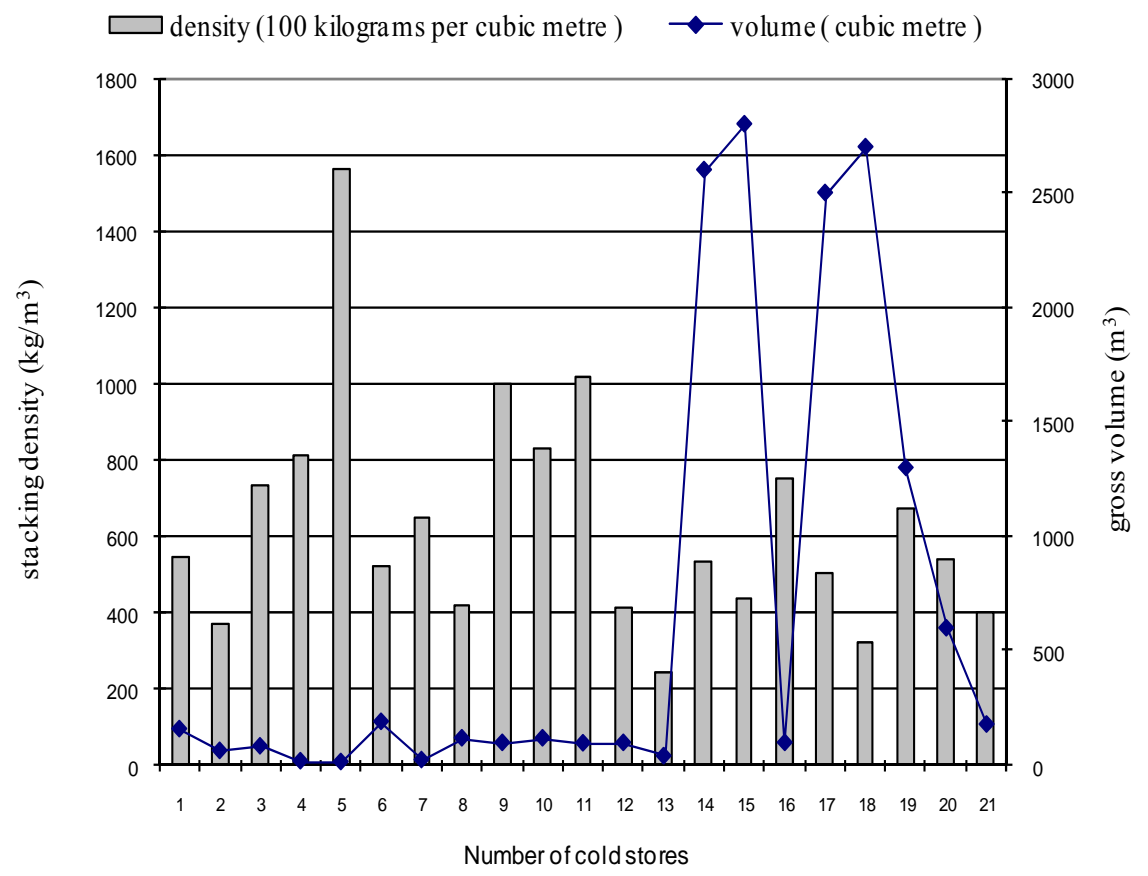

Fig. 2 Stacking density of foodstuff and gross volume of investigated cold stores.

$4{ }^{\circ} \mathrm{C}$, that is $53.8 \%$; those whose temperatures are equal to $0{ }^{\circ} \mathrm{C}$, that is $38.5 \%$; those with temperatures below $0{ }^{\circ} \mathrm{C}$, that is $7.7 \%$.

The temperature range recommended for the preservation of meat, poultry and fish in the field of refrigeration is between 0 and $4{ }^{\circ} \mathrm{C}$. However, $46.2 \%$ of these rooms do not meet the standard.

The causes of this failure to comply with the storage temperature are varied: cold stores are overcrowded because the required stacking densities by the standard are not met, causing poor air circulation and poor performance of condensing units; poor sealing of cold stores doors that are obsolete; deficiency of devices used to reduce outdoor air intakes in the cold stores (air curtains, sails flexible transparent...); unwanted stops of condensing units due to shedding of the National Power Corporation (AES Sonel), over $90 \%$ of cold stores do not have emergency unit available in case of power failure; aging of the refrigerating installation (degradation of the insulation, of the piping, gradual decrease of the compressor efficiency, excessive frost on the evaporators which reduced its efficiency); lack measuring instruments for the control of the refrigerating installation; wrong positioning of the control unit inside the cold stores (thermostat); non compliance with operating conditions use of cold stores.

\subsection{Evolution of the Curve of Relative Humidity in Cold Stores}

\subsubsection{Frozen Products}

The histogram of Fig. 1 shows three types of negative cold stores: those having a relative humidity of $90 \%$ that is $4.76 \%$; those with a relative humidity comprises between $80 \%$ and $90 \%$ that is $33.34 \%$; those with a relative humidity comprises between $20 \%$ and $80 \%$ that is $61.90 \%$.

The threshold of a good relative humidity for preserving frozen products [5] is $90 \%$. It follows from Fig. 2 that $95.24 \%$ of negative cold stores do not comply. This has the effect of causing weight loss of stored products.

\subsubsection{Refrigerated Products}

Results of investigations show two types of cold stores: those whose relative humidity ranges between $85 \% \mathrm{RH}$ and $90 \% \mathrm{RH}$, which is $23 \%$; those whose relative humidity ranges between $50 \% \mathrm{RH}$ and $80 \%$ $\mathrm{RH}$, that is $77 \%$.

The threshold for a good relative humidity for 
refrigerated products is ranging between $85 \%$ and $90 \%$. Authors note that $77 \%$ of cold stores are amazing.

The most advanced causes from our investigation are as follows: (1) refrigerating service men do not control the relative humidity of their cold stores (no measuring devices); (2) technicians are not aware of the technical adjustment of relative humidity in cold stores and managers are not aware of the importance of the concept of relative humidity in cold stores.

\subsection{Evolution of Foodstuff Stacking Density in Cold} Stores

\subsubsection{Frozen Products}

The histogram in Fig. 2 allows us to identify three types of negative cold stores: those whose stacking density are between $160 \mathrm{~kg} / \mathrm{m}^{3}$ and $300 \mathrm{~kg} / \mathrm{m}^{3}$ that is $4.76 \%$; those whose stacking density are between 300 $\mathrm{kg} / \mathrm{m}^{3}$ and $400 \mathrm{~kg} / \mathrm{m}^{3}$ that is $14.28 \%$; those whose stacking density is greater than $400 \mathrm{~kg} / \mathrm{m}^{3}$ that is $80.96 \%$.

The literature [5] shows that the normal density varies between $300 \mathrm{~kg} / \mathrm{m}^{3}$ and $400 \mathrm{~kg} / \mathrm{m}^{3}$. But the investigation shows that $85.72 \%$ do not meet this density.

\subsubsection{Refrigerated Products}

Results of investigations show that there are only two classes of positive cold stores; one whose stacking density is between $160 \mathrm{~kg} / \mathrm{m}^{3}$ and $300 \mathrm{~kg} / \mathrm{m}^{3}$ that is $77 \%$. The most extreme case where stacking density is greater than $300 \mathrm{~kg} / \mathrm{m}^{3}$ is $23 \%$. The recommended density is $160 \mathrm{~kg} / \mathrm{m}^{3}$, so we can deduce that, none of these cold stores does not meet the standard.

Authors can deduce that cold stores are usually overloaded. Thus cause a poor circulation of air in the cold stores which lead to a heterogeneity in temperature and the humidity of air.

\subsection{Air Change}

In cold stores surveyed, we found the absence of air change device regardless of the size of cold stores.

The fear of additional costs leads managers of cold stores not to take adequate measures to ensure the air renewal.

\subsection{Commercialisation and Sales}

Food commercialisation is generally done in sub-Saharan countries through small informal sales in big urban commercial centres. Informal sales are the most widely spread (more than $80 \%$ of the market); it is usually done following a disordered manners in markets as well as in residential areas, and is practiced in small retail shops and market stall at the road sides. Of course, in this case, nothing can assure a good cold chain even if the use of small refrigerators and freezers in shops [18]. It is to be noted that the use of such home machines give no guaranty because of their poor manipulation. In fact, all the merchants are just interested in giving their products the cooling, they require to conserve their market value, hence satisfying their clients.

Big urban commercial centres (supermarkets, big shops, restaurants, bakeries...) have appropriate refrigeration equipments that are used for the commercialisation of sensitive food items. Some of them include refrigerated display case, refrigerated cabinet, reach-in and commercial refrigerator. The few thaws to be noted here are the following:

(1) The absence of a strict display temperature control due to the faculty state of thermostats, as a result of their frequent repairs;

(2) The poor usage of machines (overload of food stuffs, the use of inappropriate surfaces).

This situation arises due to the ignorance of managers of such shops and the absence of a vigorous public service implication and even due to the unawareness of consumers relative to the conditions required for the proper conservation of sensitive foodstuffs.

\subsection{Training of Managers and Technicians on Food Preservation}

The collected data show that more than $95 \%$ do not known: techniques of food preservation; the standards 
on the preservation of perishable foodstuff; the concepts of microbiology applied to food; the concept of the quality of chilled or frozen; over $96 \%$ of managers believe that the cold temperature compliance is the most important criterion for preserving perishables.

\section{Discussion}

Analysing objectively the alarming situation of the cold chain in the sub-Saharan enabled us to come out with a numbers of causes, the principal of which is poverty. This poverty is materialised by the inaccessibility of refrigerated equipments at different levels of the cold chain: the limited capital of the importers, producers and merchants hinders them from getting into possession of adequate production, stacking, transportation and distribution equipments; the low purchasing power of consumers make them unable to get refrigerators and freezers for home conservation of food; low state and administration budget for the implementation of the various strategies or regulations. Apart from poverty, there are other causes such as: the ignorance and the poor sensitisation of consumers and managers on the importance of the respect of cold chain for food security and public health; the political strategies which are inappropriate to the context or poorly practiced in the field; the low technological level of technicians, which have the following consequences: the short life expectancy of refrigeration equipment caused by their poor operation and maintenance management; the poor use of these equipments causing energy wastage, makes refrigeration more and more expensive; the intervention of foreign technicians for specific tasks also rises the cost of refrigeration; the high cost of electrical energy, which does not promote the use of conservation techniques through refrigeration or, leads to inappropriate practices such as voluntary interruption of refrigeration equipments, without taking into consideration the internal temperature in an attempt to save energy.

Many solutions have been envisaged to improvise on the cold chain in the sub-Saharan countries:

(1) Sensitisation and training: We believe that the first action to be undertaken is the education, sensitisation and training of social groups at different levels, due to its low cost and the ease with which it can be implemented. At the level of basic education, notions on the cold chain could be introduced into subjects of different basic levels (classes 5 and 6 of primary schools or forms 1 and 2 of secondary schools). These elementary notions could be based on: conditions and techniques of food preservation (dairy products, meat, fish, etc.); the proper use of domestic refrigeration equipment. Lower classes are chosen in order that a greater range of the population be touched, considering the low provision of schools in the sub-Saharan countries. At the level of producers, importers and merchants, sensitisation could be done through seminars and workshop training based on: standards following the quality of agricultural and animal production; storage techniques and their impacts on the quality and duration of food conservation; display techniques of foodstuffs in commercial supermarkets, the proper use of commercial refrigeration equipments; transport refrigeration techniques. These trainings are a prerequisite to carry on strict and even repressive controls at different steps of the cold chain. At the level of technicians and operators of refrigeration equipments, a more adequate training is required. The training must stressed on: the notions on optimum managements of equipments (energy saving); modern control techniques which includes food quality (the mastering parameters such as temperature, relative humidity, air speed, air quality) and an optimum functioning of equipments in the case with electronic regulation systems, microcontrollers systems. Public authorities and financial bakers have a primordial role either in the establishment of efficient training and well equipped structures, or in the upgrading of 
training programs in actual structures. At the level of the populations and even decision makers, the media plays a crucial role in sensitisation. They have to assure the relay of classical training. Commercials and instructive documentaries on elementary rules of food conservation and their effects on health have to be permanently broadcasted by public as well as private media. These types of mediated initiatives already exist, initiated by organisms such as WHO and WFP, but rarely concern cold chain and its importance.

(2) External support: Just like in others domains, external partnership should also be perceptible when it comes to the improvement of the cold chain in the sub-Saharan. This partnership is done through international organisms by bilateral or multilateral governmental collaborations. It could be based on: the reinforcement of training quality (training of trainers, the equipment of training centre); financial assistance for media actions towards sensitisation; pressurizing politicians in order that they take better strategies.

(3) Promotion of new conservation techniques: If we consider the few people who follow meticulously all the cold chain steps as well as the low percentage of refrigeration machines in household of sub-Saharan countries, then the necessity of promoting other conservation techniques, adapted to the local food types becomes indispensable. Indeed making efforts to assure a complete cold chain would be in vain, so long as the consumer is unable to respect the last stage of this chain due to the lack of a refrigerator. Given that it's almost impossible to supply refrigerators to all homes; it is nevertheless realistic to get better food security by turning to conservation technique such as drying, smoking or salting. These techniques are advantageous in the sense that they are simple and relatively cheaper even though some nutritive values of the foodstuffs are lost. A mastery of these techniques as well as their spreading will be necessary. Research works undertaken in this domain should then be financially sustained.

\section{Conclusion}

An investigation has been carrying out on the storage conditions and distribution of perishable foodstuffs in sub-Saharan Africa: the case of Cameroon with a procedure meeting with the standard. In the sub-Saharan Africa, the cold chain from the production stage to the stage of consumption is still uncertain. It is characterised by a poor implementation of food preservation conditions, the low or wrong control of products and their conditioning at different stages, and the inappropriate use of refrigeration equipments and restitution for Sensitisation of people. The consequences of this situation can be observed through the further outbreak of food poisoning and through the reduction in quantity and in quality of available food stocks, all of thesis leading to food insecurity. In this area of countries, an outline of the possible remedies to this situation would be: education; the training and the sensitisation of the different population groups without leaving out the promotion of alternative food preservation techniques such as drying or smoking.

\section{References}

[1] IIF, Institut International du Froid, La maitrise de la chaîne du froid pour l'hygiène et la qualité des aliments, Bulletin de 1'IIF N², Paris, France, 2003.

[2] B. Commère, F. Billiard, La chaîne du froid dans l'agroalimentaire, Techniques de l'Ingénieur, 1999.

[3] IIF, Institut International du Froid, Les techniques du Froid dans les pays chauds et en développement, 1976, pp. 94-105.

[4] ATP, Agreement on the International Carriage of Perishable Foodstuffs and on the Special Equipment to be used for such Carriage, United Nations, ECE, Geneva, 1996.

[5] EU Directive 89/108 on the Approximation of the Laws of the Member States relating to Quick-Frozen Foodstuffs for Human Consumption (89/109/CEE).

[6] L.B. Sorensen, Législation concernant les denrées surgelées, Bulletin de l'IIF-n 4, 2002.

[7] M. Jul, The Quality of Frozen Food, Academic Press, 1984.

[8] IIF, Institut International du Froid, Conditions recommandées pour l'entreposage frigorifique des 
produits périssables, Bulletin de l'IIF, Paris France, 1967.

[9] C. Daniel, Application Frigorifiques tome 2, Paris France, PYC Edition, 1975, p. 240.

[10] C. Daniel, Application Frigorifique Tome 1, Paris France, PYC Edition, 1975, pp. 121-134.

[11] Décret $\mathrm{N}^{\circ} 75 / 527$ du 15 Juillet 1975 Portant réglementation des Etablissements d'exploitation en matière d'élevage et des industries animales.

[12] Décret $N^{\circ} 76 / 420$ du 14 septembre 1976 Portant réglementation de l'élevage, de la circulation et de l'exploitation du bétail.

[13] Décret $N^{\circ} 86 / 711$ du 14 Juin 1986 fixant les modalités d'inspection sanitaires et vétérinaires.

[14] Extrait de l'arrêté du $1^{\text {er }}$ Octobre 1937 fixant les règles générales d'hygiène et de salubrité publique à appliquer dans le territoire du Cameroun sous mandant français.

[15] R. Devaux, Introduction à la chimie alimentaire. Applications Industrielles, Cours IFFI, Paris, France, 1986.

[16] MINEPIA, Ministère de l'Elevage, des Pêches et des Industries Animales du Cameroun, www.minepia.gov.cm.

[17] Laboratoire de Froid et Climatisation de l'ENSET, Enquête sur les normes et méthodes de conservation des produits animaux dans les chambres froides au Cameroun, Université de Douala, 2010.

[18] Laboratoire de Froid et Climatisation de l'ENSET, Enquête nationale sur la consommation énergétique des équipements de production de froid au Cameroun, Université de Douala, 1997. 